\title{
Editorial: Asia-Pacific Science Education (APSE): Challenged to Lead in Uncertain Times
}

\author{
Sonya N. Martin \\ Editor-in-Chief \\ Department of Earth Science Education, Seoul National University \\ o8826, Seoul, Republic of Korea \\ sonya_martin@fastmail.com
}

Received: 1 July 2020 | Accepted: 1 July 2020

This editorial was originally only intended to be an announcement of new changes for the journal and an invitation for readers to continue to read and share their work with us in the coming years. However, the emergence of a global pandemic has revealed the critical need for scholars to have a dedicated space for publishing research that describes how the pandemic has had an impact on science teaching and learning in the Asia-Pacific region. Now, more than ever, we need journals like Asia-Pacific Science Education (APSE) that can amplify the voices of researchers from countries not traditionally included in mainstream science education journals. Herein, I briefly re-introduce APSE to our readers and then provide an analysis of publication trends in four top science education journals to show why publishing outlets like APSE are so important. I conclude this editorial with an introduction to nine articles published in this first issue, which includes a special set of six papers focused on earth science, climate change education, and environmental education and three additional papers addressing different issues in science education in Vietnam, Singapore, and Indonesia.

(Re)introducing APSE to our Readers

The past year brought with it some important changes for APSE in both our editorial team and our publisher. Last spring, I transitioned from my position as Co-Editor to become Editor-in-Chief, and Phil-Seok Oh joined Hye-Eun Chu and Nam-Hwa Kang as Co-Editors. In addition, Brill|Sense is now publishing 
two issues of APSE per year rather than one, as was previously published by Springer. In this first issue, I remind new and returning readers about the origins of APSE, reaffirm the aims and scope of the journal, and introduce some of the features of our journal that make it unique in its support of scholars who are non-native English speakers from the Asia-Pacific region.

\subsection{Origins, Aims, and Scope}

The Korean Association for Science Education (KASE), which was founded in 1976 and has more than 3,500 members, established APSE in 2015 to provide an English language science education journal that could support the development of science educators and researchers in the Republic of Korea (hereafter referred to as Korea), the Asia-Pacific region, and beyond. APSE accepts papers with a broad range of content, so readers will find a variety of articles exploring various issues related to K-12 and university-level science classrooms and research on teaching and learning in informal science education settings. APSE also welcomes manuscripts employing a variety of methodological approaches, including quantitative research designs and qualitative and mixed-methods studies.

\subsection{Open Access to Increase Reader Accessibility}

At APSE we have a strong commitment to make sure that all articles are made freely and permanently accessible without subscription charges or registration barriers. For this reason, we established APSE as an open access journal. Open access publishing requires authors or institutions to pay an article-processing charge (APC) to the publisher, who then hosts the article in perpetuity. The APC makes the article available free of charge to anyone who wishes to access it. This means that authors who publish with APSE hold the copyrights to their articles and have the right to use, reproduce, or disseminate their articles freely. In addition, because we are an open access journal, all publications from the first five issues of APSE are permanently archived on both our Springer website and are also accessible via links at our new Brill|Sense website. With open access publishing, content can continue to be shared and accessed across platforms so that even if journals change publishers, authors and readers can still freely access all content.

Providing content to users free of charge has been having a real impact, as evidenced by the journal's analytic data of visits, paper views, and downloads. Last year we averaged about 1,00o unique visits per month from readers in the Asia-Pacific region and beyond. When this data is broken down geographically, we found we have a large number of readers accessing content from India, the United States, the Philippines, Indonesia, and Korea. In addition, we had a considerable number of visits from readers in Malaysia, Thailand, the United 
Kingdom, and Turkey. As of late June 2020, APSE articles have been accessed nearly 106,000 times — not including when readers are re-directed from third party links, such as Cross Reference or Google. In the last six months alone, APSE articles have been accessed directly more than 21,000 times. Analysis of access data for individual papers revealed that articles published in APSE have been accessed on average about 2,300 times each. Each article has been accessed at least 350 times and some have been accessed more than 5,000 times. This means that papers published by APSE have relatively high potential to have an impact on the science education community.

\subsection{APSE Peer-Review and Native Language Executive Summaries}

Although APSE uses a double-blind review process, we work hard to provide a supportive peer-review process that is considerate of the challenges faced by non-native English speakers. We offer several options to support scholars, including providing a brief editor review of manuscripts to provide some suggestions for revision before peer review. We also encourage our reviewers to provide substantive feedback about their research focused on how to improve the quality of the work. Our editorial board members include scholars from different countries in the region who are committed to establishing a peerreview process that is both rigorous and supportive so that we can strengthen our research community and publish top-quality studies. As Editor, I write decision letters with explicit details to improve a paper for publication, and I may invite authors to engage in a video chat to gain more insight into the purpose of a study so that I can offer suggestions to help the author revise and resubmit their work for review. I can also suggest affordable and trusted English-language editing services to improve writing quality before or after peer-review. APSE also provides the opportunity to prepare executive summaries of accepted articles in the author's native language to allow researchers to share their work with scholars and teachers in local contexts while also publishing in English. We do this so that teachers and policy makers can benefit from research even if it is not fully available in the local language. Native-language executive summaries help researchers to share their work in English without sacrificing opportunities for local community members to benefit from their research. Community?

Response to the global health crisis introduced by COvD-19 has had a significant impact on education at all levels in every context around the world. The 
disruption to education and subsequent recovery efforts being led by educators, students, and families have laid bare many challenges and inequities in schooling and in society that have long needed to be addressed. As school closures have extended beyond days into months, educators, students, and parents are raising more questions than ever about the goals and purpose of schools and the roles and responsibilities for teachers and learners in traditional classrooms. At the same time, global media efforts have made clear the critical importance of science understanding and effective communication for informing citizens how to stay healthy and prevent the spread of the coronavirus. Global media coverage of the pandemic has also made clear the need for diverse channels for accessing and disseminating content from different perspectives. Initial news accounts of the virus from Western media sources failed to challenge racially charged stereotypes or to provide context needed for understanding the approaches taken by different governments to combat the virus.

As many of the initially hardest hit countries in the Asia-Pacific region have made some progress to contain the transmission of the virus, educators are now tasked with developing new teaching methods that have the potential to shift how school and science are experienced by millions of students. Many Asian countries, such as Korea, have implemented rapid responses to education disruption via online and blended education. Systemic changes provide researchers with unprecedented opportunities for conducting research on how these responses have an impact on students' attitudes towards science and achievement. Additionally, research is needed to understand how in-service and preservice science teachers are adapting to these changes. Understanding how responses to the pandemic are changing educational approaches in how science is taught and learned is of critical importance. In these uncertain times, we need scholars from the Asia-Pacific region to lead the efforts to learn how these responses to the disruption of school and society could provide opportunities for teaching and learning science in new and innovative ways that could be maintained and developed in a post-pandemic era. Established as a channel for disseminating research in the Asia-Pacific region, APSE is ready to lead the way by providing a home for scholars to share current research on pandemic responses in science education.

APSE Provides a Voice for Science Educators in the Asia-Pacific Region

Five years ago, when we published our first editorial (Martin \& Chu, 2015) in the first issue of $A P S E$, we described the need for establishing a new journal dedicated to providing a voice for science education scholars from countries 
with majority Asian populations. At that time, we conducted an analysis of publications in top science education journals to verify the need for an alternative journal outlet. For this editorial, I revisited and expanded on our earlier analysis by following the same method used before (see Martin \& Siry, 2011; Martin \& Chu, 2015) to determine how many papers have been published by authors representing institutions in countries with majority Asian populations in top-ranked science education journals over an extended period of time. In the original analysis, all published articles were included in analysis with exception of editor addendums and corrections. In the analysis of new data $\left(2015^{-2020}\right)$ I used the same method, except that I also excluded book reviews. Four journals were selected: the Journal of Research in Science Teaching (JRST), Science Education (SE), Research in Science Education (RISE), and the International Journal of Science Education (IJSE). These journals were selected because they are included in the Social Sciences Citation Index (SSCI) and they focus solely on science education (not math or technology education or the learning sciences). These four journals are all published in English, are accessible in on-line and print formats, and are widely accessed by researchers in the field of science education.

Analysis focused on identifying the university affiliation and geographical location for each author and including all papers published by authors affiliated with an institution in a country in the geographical Asia-Pacific region (including countries in Central and Southeast Asia). We included all papers except corrections or addendums, regardless of authorship position (i.e., whether they were lead author, last author, or other position). Authors affiliated with institutions in countries where the majority of the population are not identified as racially/ethnically Asian were not included. For example, less than $10 \%$ of the total population of Australia and New Zealand are racially/ ethnically identified as Asian, so authors representing institutions in these countries were not included even though Australia is geographically located in the Asia-Pacific region. Again, it is important to note that institutional affiliation is not correlated with the author's nationality or ethnicity, but merely identifies author's institutional affiliation.

Our initial analysis from 2010-2014 showed that about 9.7\% of all papers authored in all four journals during this 5-year period included an author representing an institution in an Asian majority country (Martin \& Chu, 2015). New analysis shows that over more than a 10-year period, publications by researchers at institutions in Asian countries represented only $3-5 \%$ of all publications in $J R S T$ and $S E$ and about $8-16 \%$ in IJSE and RISE. Table 1 offers a comparative analysis of publication trends in these four journals from January 2010 to June 2020. 
TABLE 1 A comparative analysis of journal publications with authors representing institutions in Asian majority countries from 2010-202O

\begin{tabular}{|c|c|c|c|c|c|}
\hline \multirow[t]{2}{*}{ Journal } & \multicolumn{2}{|c|}{$\begin{array}{l}\text { Total number of } \\
\text { publications }\end{array}$} & \multicolumn{2}{|c|}{$\begin{array}{l}\text { Publications } \\
\text { representing authors } \\
\text { from institutions in } \\
\text { Asian-majority countries } \\
\text { (total \%) }\end{array}$} & $\begin{array}{l}\text { Change in } \\
\text { representation } \\
\text { over 1o years } \\
(+/-\%)\end{array}$ \\
\hline & $2010-2014$ & $2015^{-2020}$ & $2010-2014$ & $2015^{-2020}$ & \\
\hline JRST & 236 & 298 & $8(3.4 \%)$ & $13(4.4 \%)$ & $+1.0 \%$ \\
\hline$S E$ & 205 & 265 & $10(4.8 \%)$ & $10(3.8 \%)$ & $-1.0 \%$ \\
\hline RISE & 292 & 337 & $25(8.6 \%)$ & $39(11.6 \%)$ & $+3.0 \%$ \\
\hline IJSE & 576 & 673 & $84(14.6 \%)$ & $107(15.8 \%)$ & $+1.0 \%$ \\
\hline Total (\%) & 1309 & 1573 & $127(9.7 \%)$ & $169(10.7 \%)$ & $+1.0 \%$ \\
\hline
\end{tabular}

My secondary analysis found that there has been very little change in the number of publications authored by scholars representing institutions in Asian majority countries in these four science education journals. In contrast, however, since 2015 the APSE journal has published six issues containing 55 articles written by authors entirely from institutions in majority Asian countries or by authors conducting research on issues related to the Asian-diaspora. APSE has a wide selection of papers published by authors from institutions in Korea, Singapore, China, Taiwan, Hong Kong, and Japan. In addition, APSE has published several articles by colleagues from Thailand, Indonesia, the Philippines, Malaysia, Macau, and Vietnam. Some of these papers have appeared as part of a continuing special issue describing science teacher education and teacher preparation in every country in the region. Currently there are 10 papers completed for this series. Some examples of these are a review of elementary science teacher education in Korea (Park, 2019), a retrospective of developments in science teacher education in Taiwan (Tuan \& Lu, 2019), and a review of the Malaysia's science teacher education program (Mamud et al., 2018).

\subsection{APSE Welcomes Comparative Studies and Research on the Experiences of the Asian Diaspora}

As noted previously, APSE also includes research from colleagues in the United States, Australia, Canada, New Zealand, and Germany who have conducted 
comparative analysis studies with researchers in the Asia-Pacific or with members of the Asian diaspora in other parts of the world. Some examples include Minjung Ryu's (2015) qualitative study exploring identity and science learning of Korean transnational students in an advanced biology course in a high school in the United States. Other examples include historical comparative studies examining similarities and differences in secondary science education in Britain, Japan, and the United States (Isozaki, 2016) and a comparison of German and Japanese student teachers' views on creativity in chemistry (Semmler et al., 2018). APSE encourages such studies from colleagues outside of the Asia-Pacific region because they help to provide context for understanding how science and science education research are informed by socio-historical contexts, and they encourage a cross-pollination of ideas and thought about science and diversity in different areas of the world.

\section{3}

\section{Overview of this Issue}

This issue features a special set of papers related to earth science, climate change education, and environmental education in the Asia-Pacific Region. Earth science education is a unique field of research and teacher preparation in many parts of the world, especially in countries in the Asia-Pacific region. This special set of papers highlights the work of 10 researchers who have explored diverse topics in the fields of earth science, climate education, and environmental education.

Drawing from an analysis of 16 Korean and international climate change education (CCE) programs, Na-Eun Park and colleagues developed an analytical framework to identify structure and content of different programs and to categorize action-emphasized climate change education (AECCE) programs. Their analysis found that most CCE programs target primary education and place limited emphasis on promoting student action. Alternatively, AECCEcategorized programs tended to promote more action, but there were differences between Korean and international programs with regard to what values and attitudes were fostered and what level of actions was encouraged.

In their discussion of climate change club projects, Woo-Yong Park and Chan-Jong Kim describe activities that students investigated as part of their participation in club activities aimed at developing scientific models of causes of climate change. They found that five types of competences of ecological citizenship were fostered through club activities, some of which served as resources for social action for fighting climate change, which they feel is essential for developing students' ecological citizenship. 
Ji-Ho Kim and Chan-Jong Kim share findings from a study exploring types and intensities of students' emotions related to participation in school-based ssi club projects related to climate change. This study describes how students explored local problems related to climate change and what they did to plan and participate in social actions. Using the control-value theory, these researchers analyzed how students' emotions changed when planning and participating in social action and considered which emotions were important for compelling students to act.

Yoon-Sung Choi and colleagues offer a description of middle school students' gestures during a geological field trip using hermeneutics to interpret meaning from student gestures. The researchers identified frequently used gestures, which served either social or science communication purposes. This study offers implications about the role of gestures for communicating geoscience content and raises questions about the potential for gestures to be used by educators, especially during experiential learning activities.

The final paper in this set, authored by Young-Shin Park and Jo Hoon Park, introduced exemplary explicit teaching strategies enacted by a middle school teacher during a STEAM program. The authors used O-TOP (Oregon Collaborative for Excellence in the Preparation [OCEPT] Teaching Observation Protocol) and NGSS 8 Science Practices (Next Generation Science Standards) to identify and describe three stages of STEAM education: understanding context presentation, performing creative design, and experiencing emotional touch. This study offers implications about the need for STEAM education professional development for teachers.

The final paper in this series, authored by Leslie Sprong and Sonya Martin, shares results from a study that used the Draw-an-Environment Test to reveal how middle school students in a rural community in India perceive their environment. The researchers found that students' drawings do not necessarily reflect the reality of the local environment. The researchers describe the larger goals of the study, which sought to share students' perceptions of the environment with local educators to develop a responsive environmental education curriculum that could challenge and expand students' conceptions, which could help to improve environmental outcomes for India.

This issue included another paper in an APSE series focused on science teacher education in the Asia-Pacific. Nguyen Van Hien and colleagues contributed to this series by describing past, current, and future trends in science teacher preparation and professional development in Vietnam. This paper describes the general education system of Vietnam and explores how changes in the overall structure and organization of the education system have 
helped to develop and advance many aspects of teacher preparation, curriculum development, and student outcomes. The authors provide readers with an introduction to the new national general education program and discuss some key challenges that will be faced by researchers and teacher educators in the future.

Vanessa Vinodhen presents a historical analysis of the development of science education in Singapore from 1997 to 2011 with a focus on understanding how a period known as the ability-driven period had an impact on two main educational initiatives: the Teach Less, Learn More initiative and the Information Technology Masterplan. The author describes how these initiatives had an impact on science education and science culture. She concludes by discussing the value of historical analysis for understanding how policy affects practice over time.

The final paper in this issue by Ai Nurlaelasari Rusmana and colleagues describes an intervention to debias overconfidence among students using a model known as the KAAR (knowledge, awareness, action, and reflection) model. Ninety Indonesian undergraduate students were subjects of this study. The researchers describe how intervention activities, such as having students watch a video about overconfidence, can help to reduce students' overconfidence, which can benefit students because overconfidence bias has been shown to hinder students' metacognitive abilities.

\section{Invitation to Continue Changing the Future of Science Education}

APSE welcomes guest editors to develop a call for papers for special issues because we want our readers will develop a sense of ownership for our journal. APSE published a very popular special issue (see Fulmer, Chu, \& Martin, 2018, for details) focused on teacher action research in Singapore. This issue was guest edited by APSE Editorial Board members Dr. Gavin Fulmer (USA) and Co-Editor Dr. Hye-Eun Chu (Australia) who both previously worked in Singapore. We invite you to submit proposals for special issues and to submit individual manuscripts to APSE so we can continue to change the future of science education. Some of the articles in this special issue have been downloaded more than 5,000 times! Our next issue (December 2020, Volume 6, Issue 2) will include some invited papers from colleagues outside of the region who will share work related to diversity and equity in science education with the goal of starting more conversations and research around these topics in the Asia-Pacific region. 


\section{Acknowledgments}

I wish to express our sincere gratitude to Dr. Jinwoong Song and Dr. Hae-Ae Seo who served as the first two Editors-in-Chief for APSE. They have each worked hard to make the journal grow and develop. I also want to thank APSE Co-Editors, Dr. Phil-Seok Oh, Dr. Hye-Eun Chu and Dr. Nam-Hwa Kang for all of their tireless support of our journal. I want to acknowledge the effort and support our dedicated editorial board members and reviewers who provide our authors with sincere and constructive feedback that is helping to expand and improve science education scholarship in the region. I want to acknowledge the leadership of Dr. Chan-Jong Kim as President of KASE. He has worked tirelessly to support the development of APSE over the last 2 years. And finally, I want to thank APSE Editorial Assistants Dr. Jisun Park (2015-19) and Ms. Da Yeon Kang (2019-present)—without whom our current success would not be possible.

\section{About the Author}

Sonya N. Martin is an Associate Professor in the Department of Earth Science Education at Seoul National University in Seoul, Republic of Korea. Sonya holds a bachelor's degree in Biology from Bryn Mawr College, and master's degrees in Elementary Education and in Chemistry Education from the University of Pennsylvania in the United States. She also holds a doctoral degree in Science Education from Curtin University in Australia. Her research focuses on identifying science teacher practices that promote learning for diverse students and on promoting the professionalization of science teachers through classroombased participatory research. She is the Editor-in-Chief of Asia-Pacific Science Education and serves as an editorial board member for Research in Science Education and Cultural Studies of Science Education.

\section{References}

Fulmer, G., Chu, H.E., \& Martin, S. (2018). The potential of teacher-led research: teachers' action research collaborations in science education in Singapore. Asia-Pacific Science Education, 4:7, 1-6.

Isozaki, T. (2016). Historical insights into British, Japanese, and US general science from the first half of the twentieth century. Asia-Pacific Science Education, 2:1, 1-16. 
Isozaki, T. (2018). Science teacher education in Japan: past, present and future. Asia-Pacific Science Education, 4:10, 1-14.

Mamud, S.N.D., Nasri, N.M., Samsudin, M.A., \& Halim, L. (2018). Science teacher education in Malaysia: challenges and way forward. Asia-Pacific Science Education, 4:8, 1-12.

Martin, S.N., \& Chu, H.E. (2015). Asia-Pacific Science Education (APSE): Expanding opportunities for publishing science education research. Asia-Pacific Science Education, 1:3, 1-18.

Martin, S.N., \& Siry, C. (2011). Networks of practice in science education research: A global context. Journal of Research in Science Teaching, 48(6), 592-623.

Park, J. (2019). Elementary science teacher education in Korea: past, present and future. Asia-Pacific Science Education, 5:20, 1-11.

Ryu, M. (2015). An examination of Melody's identities, contexts, and learning in a US science classroom: implications for science education of Asian transnational students. Asia-Pacific Science Education, 1:4, 1-30.

Semmler, L., Uchinokura, S., \& Pietzner, V. (2018). Comparison of German and Japanese students teachers' views on creativity in chemistry class. Asia-Pacific Science Education, 4:9, 1-29.

Tuan, H.L., \& Lu, Y.L. (2019). Science teacher education in Taiwan: past, present and future. Asia-Pacific Science Education, 5:15, 1-22. 